\title{
Morphological Traits and Chemical Composition of Hazelnut from Different Geographical Origins: A Review
}

\author{
Katarzyna Król $1 D$ and Magdalena Gantner * \\ Department of Functional and Organic Food, Institute of Human Nutrition Sciences, Warsaw University of \\ Life Sciences, Nowoursynowska str. 159c, 02-776 Warsaw, Poland; katarzyna_krol@sggw.edu.pl \\ * Correspondence: magdalena_gantner@sggw.edu.pl
}

Received: 29 July 2020; Accepted: 21 August 2020; Published: 25 August 2020

\begin{abstract}
Hazelnut (Corylus avellana L.) is a popular tree nut worldwide, and in recent years, the production of hazelnuts has increased in many countries due to large investments improving agricultural techniques and the selection of new cultivars. Turkey, the leader of global hazelnut production, has shown that supply can strongly fluctuate, which leads to peak prices and market instability. In this review, an overview of the morphological traits, nutritional value, fatty acid composition, tocopherols, and future prospects of hazelnut production are described. Furthermore, information regarding hazelnuts from different geographical origins (Chile, Croatia, Iran, Italy, Oregon (US), Poland, Portugal, Serbia, Spain, and Turkey; total of 22 cultivars) to enhance the utilization of hazelnut cultivars from newly producing orchards and origins is comprehensively summarized.
\end{abstract}

Keywords: Corylus avellana L.; filbert; fatty acid profile; nutritional value; tocopherols

\section{Introduction}

Hazelnut (Corylus avellana L.) is one of the most important nut crops worldwide, ranking third in the global nut market, with production exceeding 863 thousand tons per year [1]. The global hazelnut market is forecast to grow between 2017-2021, increasing its worth from USD 4.15 billion to USD 5.75 billion [2]. Turkey is the leading hazelnut producer (53\%), followed by Italy (13\%), Azerbaijan (5\%), United States (5\%), China (2.5\%), Georgia, Iran, Poland, France, Spain, and Chile $(<2 \%$ each) [1] and world's harvested area of hazelnut exceeds 660,000 ha [3]. Hazelnuts are mostly sold to processing companies (shelled nuts), whereas fresh consumption (in-shell nuts) only accounts for $10 \%$ of the total harvest [4]. In recent years, the production of hazelnuts has increased in countries with low production rates due to large investments helping to improve established agricultural techniques and select new cultivars. This situation has led to increased competition between the main hazelnut producers [5].

The hazelnut is in itself a fruit of the hazel, widely used in chocolate and confectionery and bakery industries, and also as an ingredient for many other food products (i.e., cookies, ice cream, breakfast cereals, coffee, snacks, liqueurs, spreads) [3,6]. It has been labeled as a functional food because its consumption is associated with several human health benefits owing to a high concentration of bioactive compounds, including sterols, tocopherols, phenolic acids and flavonols [7-10]. Moreover, in hazelnut tissues (hard shells, green shell, leaves, and kernels) the paclitaxel and other taxanes were detected; diterpenoids, secondary metabolites which are an effective anticancer agent, show an outstanding activity against various cancers [11-14]. Hazelnut cultivar identification is commonly based on the morphological traits of kernels and nuts, in which their physical traits are necessary to project the hazelnuts processing, lines because the machinery is influenced by the size and shape of the food [15]. However, to obtain a clear identification of hazelnut cultivars, while considering 
their geographic origin, the implementation of genetic and/or metabolomic markers coupled with statistical analysis is a more appropriate method [16]. Nevertheless, these methods are laborious, time consuming, and expensive.

Due to the outcrossing nature of hazelnut, genetic diversity is found among existing cultivars. There is an array of varieties cultivated in commercial orchards, each with its own characteristics and demands. Mehlenbacher [17] described 400 selected cultivars from various countries and often, cultivars with different names have identical genotype markers, which leads to confusion and incorrect cultivar labeling during the production process. Gürcan et al. [18] suggested that the genetic structure population of European hazelnut consists of seven main populations: Azerbaijan/Georgia, Central Anatolia, England, Italy, Spain, Black Sea, and Central Europe (Germany, Poland, Moscow) based on the study of 582 accessions indicating diversity between clusters. In addition to the genotype, agricultural techniques, postharvest management, and orchard location all affect the morphological, physical, and chemical characteristics of hazelnuts, leading to preferred varieties in each growing area $[19,20]$. Modern agriculture requires high yield for high profitability, and the planting of incorrectly labeled cultivars, not resistant to climate in a given country, creates conditions that reduces production and create irregular fruiting in production plantations [21]. One of the most desirable hazelnuts on the market are Italian cultivars, Tonda di Giffoni and Tonda Gentile delle Langhe, which have gained the Protected Geographical Indication (PGI) European marks. These cultivars are characterized by their high resistance to pathogens and pests, in addition to well-shaped kernels and sensory properties, such as sweetness and low burnt aroma [22-24].

Although many hazelnut cultivars have been intensively investigated, especially those cultivated in Turkey [10,25-27] and Italy [28-31], so have those from new producing countries such as Chile [32], Iran [15,33], and Poland [34-37]. To the best of our knowledge, reviews on hazelnut physio-chemical properties are limited. Moreover, the Turkish hazelnut supply and production have strongly fluctuated in recent years, due to abiotic stresses in the plantations, causing peak prices and market instability [38]. Furthermore, Chile, China, and Azerbaijan all increasing their rank in the current international market, due to the exploitation of seasonality in contrast with European trades. In China, mainly wild cultivars of Corylus heterophylla Fisch. and Corylus mandshurica Maxim. are cultivated, however, their morphological traits and chemical compositions differ depending on the cultivars cultivated, as well as the fatty acid composition $[39,40]$.

The hazelnut plantation is, as of countries, such as Chile, have increased significantly in recent years, mainly with Tonda di Giffoni and Barcelona cultivars [32]. As a result, it is expected that by 2025, Chile will become the third highest world producer, with a cultivated area of approx. 30 thousand ha [32]. In Serbia, the hazelnut production is rather small, but it is economically important [41]. Therefore, the aim of this review was to summarize the hazelnut cultivars' morphological and chemical characteristics from different geographical origins; not only from large-scale producing countries, but also from countries with a much smaller annual production, which have a great prospect for future development. Among the investigated cultivars in this review, the most widespread and prominent cultivars with a certain origin were selected. The hazelnut chemical composition and morphological traits are directly related to the quality and shelf-life of the nuts and their derived products. This study contributes data that may be useful to food-processing companies to enhance the utilization of hazelnut cultivars from new producing orchards and origins.

\section{Cultivars Morphological Characteristics}

Nut characteristics vary between cultivars and are highly dependent on the genotype, agricultural techniques and environmental factors in the different plantation areas. Some cultivars, such as Tonda Gentile della Langhe, show lower adaptability to different climate areas, therefore, it is important to emphasize the usefulness, characteristics, and evaluation of cultivars in various areas [28,41-46]. However, identification based on traditional morphological traits may be difficult due to environmental factors [22], although 
certain factors should be considered. Table 1 lists the dimensions, mass, and sphericity of the nut and kernel, as well as the kernel ratio of the most prominent and widespread cultivars in certain countries. 
Table 1. Morphological characteristics of the nut and kernels of hazelnut cultivars from different origins.

\begin{tabular}{|c|c|c|c|c|c|c|c|c|c|c|c|c|c|}
\hline & & NUT & & & & & KERNE & & & & & & \\
\hline Origin & Cultivar & $\begin{array}{l}\text { Length } \\
(\mathrm{mm})\end{array}$ & $\begin{array}{l}\text { Width } \\
(\mathrm{mm})\end{array}$ & $\begin{array}{l}\text { Thickness } \\
\text { (mm) }\end{array}$ & $\begin{array}{l}\text { Mass } \\
\text { (g) }\end{array}$ & $\begin{array}{l}\text { Sphericity } \\
(-)\end{array}$ & $\begin{array}{l}\text { Length } \\
(\mathrm{mm})\end{array}$ & $\begin{array}{l}\text { Width } \\
(\mathrm{mm})\end{array}$ & $\begin{array}{l}\text { Thickness } \\
\text { (mm) }\end{array}$ & $\begin{array}{l}\text { Mass } \\
\text { (g) }\end{array}$ & $\begin{array}{c}\text { Sphericity } \\
(-)\end{array}$ & $\begin{array}{c}\text { Kernel } \\
\text { Ratio (\%) }\end{array}$ & References \\
\hline Chile & Tonda di Giffoni & - & - & - & $2.90-3.10$ & - & - & - & - & $1.30-1.40$ & - & $44.3-45.0$ & [32] \\
\hline Croatia & Istarski Duguljasti & - & - & - & $2.65-3.17$ & - & - & - & - & $1.18-1.35$ & - & 43.50 & [47] \\
\hline \multirow{2}{*}{ Iran } & Pashmine & 17.81 & 16.09 & 14.09 & 1.38 & 0.89 & 13.52 & 8.09 & 8.34 & 0.48 & 0.71 & 33.21 & [15] \\
\hline & Barcelona & - & - & - & $3.30-3.80$ & - & - & - & - & - & - & $39-42$ & \\
\hline \multirow[t]{3}{*}{ Oregon } & Yamhill & - & - & - & 2.30 & - & - & - & - & - & - & - & [48] \\
\hline & Jefferson & - & - & - & 3.70 & - & - & - & - & - & - & - & \\
\hline & $\begin{array}{l}\text { Tonda Gentile } \\
\text { Romana }\end{array}$ & - & - & - & 2.50 & - & - & - & - & 1.18 & 1.03 & 47.22 & \\
\hline \multirow{3}{*}{ Italy } & Tonda di Giffoni & - & - & - & 2.65 & - & - & - & - & 1.17 & 0.98 & 43.63 & [28] \\
\hline & $\begin{array}{l}\text { Tonda Genrile delle } \\
\text { Langhe }\end{array}$ & - & - & - & 2.48 & - & - & - & - & 1.18 & 1.01 & 45.60 & \\
\hline & Barceloński & 21.40 & 20.97 & 18.97 & 2.70 & 0.85 & 16.64 & 13.99 & 12.11 & 1.22 & 0.85 & 44.9 & \\
\hline \multirow[t]{3}{*}{ Poland } & Cosfrod & 24.17 & 16.07 & 14.32 & 2.41 & 0.73 & 19.68 & 11.42 & 10.08 & 1.09 & 0.65 & 45.7 & [34] \\
\hline & Kataloński & 21.52 & 20.97 & 18.88 & 2.24 & 0.95 & 16.46 & 13.34 & 11.36 & 1.17 & 0.81 & 43.9 & \\
\hline & Davianna & - & - & - & 2.46 & - & - & - & - & 1.22 & - & 49.5 & \\
\hline \multirow[t]{3}{*}{ Portugal } & F. Coutard & - & - & - & 3.39 & - & - & - & - & 1.38 & - & 40.6 & [9] \\
\hline & M.Bollwiller & - & - & - & 2.66 & - & - & - & - & 1.27 & - & 47.9 & \\
\hline & Corabel & 18.59 & 17.25 & 15.24 & 2.18 & - & - & - & - & 0.89 & 0.91 & 42.0 & \\
\hline \multirow[t]{2}{*}{ Serbia } & Furfulak & 21.72 & 24.64 & 21.29 & 4.00 & - & - & - & - & 1.76 & 1.04 & 44.9 & [49] \\
\hline & Ennis & 26.83 & 22.64 & 20.59 & 3.97 & - & - & - & - & 1.61 & 0.86 & 41.0 & \\
\hline \multirow{3}{*}{ Spain } & Negret & - & - & - & 2.01 & - & - & - & - & 2.05 & - & 49.14 & {$[50]$} \\
\hline & Pautet & - & - & - & 2.05 & - & - & - & - & 1.01 & - & 49.07 & {$[00]$} \\
\hline & Palaz & 15.66 & 18.16 & 16.17 & 1.68 & 1.06 & 11.16 & 13.91 & 12.37 & 0.89 & 1.12 & 45.88 & \\
\hline \multirow[t]{2}{*}{ Turkey } & Çakıldak & 18.55 & 16.80 & 15.67 & 1.59 & 0.91 & 13.97 & 12.60 & 11.14 & 0.81 & 0.90 & 46.40 & [25] \\
\hline & Tombul & 16.52 & 16.66 & 15.79 & 1.48 & 0.98 & 11.63 & 12.69 & 11.96 & 0.92 & 1.04 & 47.31 & \\
\hline
\end{tabular}

"-"-no data. 
Among the different hazelnut cultivars grown in Oregon, Barcelona is the most prominent variety, accounting for more than $60 \%$ of the total production [48]. In the continental part of Croatia, Istarski duguljast $i$ is the major autochthonous cultivar [47], while Spain's main widespread cultivar is Negret, which is planted in $70 \%$ of commercial orchards [5,51].

Information on the hazelnut cultivars regarding the dimensions (length, width, and thickness) of the nut and kernel are limited, except those from Iran, Poland, Serbia and Turkey. Cultivars from Poland and Serbia are classified as possessing the highest nut dimension values, whereas those from Turkey and Iran have the lowest. The order of highest hazelnut kernel dimensions values of known cultivars is as follows: Poland $>$ Turkey $>$ Iran. Compared to other cultivars, two cultivars from Serbia (Furfulak and Ennis) have the highest mass of nut and kernel, $15-60 \%$ and $20-70 \%$, respectively. Moreover, the Barcelona cultivar, cultivated in Oregon, shows a much higher nut mass, compared with those grown under Polish climate conditions. Similarly, the Tonda di Giffoni cultivar grown in Chile exhibits morphological differences with respect to the same cultivar widely cultivated in Italy.

Sphericity is an important quality trait among hazelnut properties because spherical nuts are highly desirable for industrial processing and are more easily cracked, blanched, and roasted [15]. Furthermore, Solar and Stampar [52] stated that this property is consistent and can be used for cultivar characterization. The kernels of hazelnut from Italy and Turkey are considered the roundest, resulting in the extensive production of these cultivars, which adhere to market demands. Therefore, countries with low production rates, such as Poland, Chile, and Iran, with newly established orchards, should cultivate the most spherical nuts, which would increase competitiveness among the main hazelnut producers. The kernel percentage is well investigated among listed cultivars. Mehlenbacher et al. [53] reported that the kernel percentage is a highly repeatable characteristic that shows little variation within the same cultivar among trees, years, and locations. The lowest kernel ratio $(33 \%)$ is observed for the Pashmine cultivar from Iran, which is due to both fruit size and the insufficient amount of water required for fruits to fill in with kernel during fruit rise [21]. Cristofori et al. [28] showed that kernel ratio, and the mass of kernel and nut, are related to water availability; the lower the water supply, the lower the yield, kernel ratio and mass. The highest kernel ratio is possessed by cultivars from Spain (Negret and Pautet 49.0\%) and Portugal (Davianna; 49.5\%). In the case of other cultivars' kernel ratio, they are comparable between 41 and $47 \%$. Despite the fact, in most of the cited studies, the data of morphological traits are averaged $[34,41,50,54]$ or from only one year of harvest $[9,15,25]$, what could create limitations in the observation of seasonal changes in hazelnut cultivars.

In addition, morphological traits must be considered when selecting the hazelnut cultivar for specific food products. Mainly, products with whole hazelnuts such chocolate and pralines, require smaller and round hazelnut cultivars, which also exhibits sensory characteristics, such as higher kernel hardness, so it remains intact during manufacturing [55]. The hazelnut cultivars used in hazelnut creams and spreads should have a pleasant aroma and flavor, obtained through the roasting process, and in this purpose, the morphological traits play a minor role. Low-quality hazelnuts (e.g., non-spherical, elongated) are processed for edible oil production [56]. To conclude, the morphological and biological traits play an important role for all food companies involved in the hazelnut manufacturing chain [57].

\section{Nutritional Value}

Research on kernel composition mainly focuses on the oil content and fatty acid profile, whereas those of basic nutritional values have not been thoroughly investigated in countries such as Chile and Serbia, notwithstanding their potential effect on nut sensory characteristics. Interestingly, the nutritional characteristics of two Italian cultivars (Tonda Gentile Romana and Tonda Gentile delle Langhe) are limited or not readily available. Research into kernel composition and the perceptional capacity of sensory attributes by consumers is important for characterizing nut quality [48]. Therefore, the researchers' attention should be shifted to chemical composition, which corresponds to the taste attributes and health properties of hazelnut as well as processed products. In seven hazelnut cultivars, the fat content was lower than $60 \%$, with the Pashmine cultivar from Iran possessing the lowest fat content of 
$50.81 \%$ (Table 2). The highest fat content of $66.29 \%$ is observed for the Pautet cultivar from Portugal. Additionally, the fat content in hazelnut kernels is comparable to protein and carbohydrates, with an average content of $62-64 \%$. The protein content in hazelnut cultivars varies from $7.03 \%$ (Pautet) to $24.61 \%$ (Pashmine), and carbohydrates from $7.82 \%$ (Tombul) to $21.79 \%$ (Cosford). The hazelnut cultivars from Turkey are characterized, possessing the highest protein content and lowest carbohydrate content. The Barcelona cultivars from Oregon and Poland show similar carbohydrate content, $16.30 \%$ and $16.45 \%$, respectively. The Portugal hazelnut cultivars have the highest ash content $(4.20-5.20 \%)$, whereas other cultivars are in the range of $2.00-2.79 \%$. "-" -no data.

By comparing the data from various growing areas, it is clear that the climate can influence the proximate chemical composition of hazelnuts, due to temperature affecting lipid and protein synthesis. Cristofori et al. [28] and Cittadini et al. [58] showed that colder climates produce $3-5 \%$ higher oil content in hazelnut and walnut cultivars compared to those from warmer climates. Moreover, the influence of climate has also been highlighted in some olive cultivars, which show a decreased fruit oil content in warm climates [59]. However, in the current review, the results showed different results, mainly, the highest oil concentration is observed in countries with a warm climate (Spain), while under the Turkish and Iranian climate, the lowest oil concentration was obtained, which is consistent with previous results-despite the lack of direct evidence for the relationships between temperature and kernel oil concentration in hazelnuts. Rovira et al. [50] observed no differences of protein and mineral content between the cultivars, whereas Hosseinpour et al. [15] presented significant variation in the kernel composition, which depended on the hazelnut cultivar. Hoekstra et al. [60] showed that in plants tolerant to water stress, compatible solutes are bound to protein surfaces, thus stabilizing the native protein structure, whereas in plants sensitive to such deficiency, the proteins tend to degrade.

Table 2. Chemical composition of hazelnut cultivars from a different origin.

\begin{tabular}{|c|c|c|c|c|c|c|c|}
\hline Origin & Cultivar & $\begin{array}{l}\text { Oil Content } \\
(\%)\end{array}$ & $\begin{array}{l}\text { Protein } \\
(\%)\end{array}$ & $\begin{array}{c}\text { Carbohydrate } \\
(\%)\end{array}$ & $\begin{array}{l}\text { Ash } \\
(\%)\end{array}$ & $\begin{array}{l}\text { Moisture } \\
(\%)\end{array}$ & References \\
\hline Croatia & Istarski Duguljasti & $63.30-64.38$ & $10.87-13.13$ & $18.87-19.78$ & $2.51-2.59$ & $3.11-3.21$ & [47] \\
\hline \multirow[t]{2}{*}{ Iran } & Pashmine & 50.81 & 24.61 & 14.56 & 3.83 & - & [33] \\
\hline & Tonda Gentile Romana & 62.57 & - & - & - & - & [54] \\
\hline \multirow[t]{3}{*}{ Italy } & Tonda di Giffoni & 61.30 & 14.00 & 18.08 & 2.34 & 4.28 & [61] \\
\hline & $\begin{array}{l}\text { Tonda Gentile delle } \\
\text { Langhe }\end{array}$ & 59.25 & - & - & - & - & [54] \\
\hline & Barcelona & 59.10 & 18.20 & 16.30 & 2.00 & 4.40 & \\
\hline \multirow[t]{3}{*}{ Oregon } & Yamhill & 65.00 & 14.50 & 15.70 & 2.20 & 2.70 & [62] \\
\hline & Jefferson & 57.10 & 17.10 & 19.80 & 2.20 & 3.90 & \\
\hline & Barceloński & 62.43 & 12.15 & 16.45 & 2.79 & 6.18 & \\
\hline \multirow[t]{3}{*}{ Poland } & Cosfrod & 59.92 & 12.52 & 21.79 & 2.32 & 3.45 & [34] \\
\hline & Kataloński & 62.54 & 11.50 & 18.69 & 2.81 & 4.46 & \\
\hline & Davianna & 56.30 & 15.70 & 19.90 & 5.2 & 3.0 & \\
\hline \multirow[t]{2}{*}{ Portugal } & F. Coutard & 60.60 & 14.80 & 14.40 & 4.6 & 5.6 & [9] \\
\hline & M. Bollwiller & 61.60 & 15.10 & 15.60 & 4.2 & 3.5 & \\
\hline \multirow{3}{*}{ Spain } & Negret & 67.45 & 16.05 & - & 2.60 & - & {$[501$} \\
\hline & Pautet & 66.29 & 7.03 & - & 2.46 & - & [50] \\
\hline & Palaz & 58.21 & 22.06 & 9.79 & 2.29 & - & \\
\hline \multirow[t]{2}{*}{ Turkey } & Çakıldak & 57.39 & 20.85 & 12.16 & 2.22 & - & [25] \\
\hline & Tombul & 60.76 & 21.21 & 7.82 & 2.36 & - & \\
\hline
\end{tabular}

\section{Fatty Acid Composition}

Research on fatty acid composition in hazelnuts has been widely studied, other than in Chile and Serbia. The order of contribution of fatty acids in hazelnut decreases as follows: oleic acid $>$ linoleic acid $>$ palmitic acid > stearic acid > linolenic acid (Figure 1). Oleic acid (C18:1c9) is the predominant fatty acid in each hazelnut cultivar, with the highest content observed in cultivars from Italy (Tonda Gentile Romana, 83.59\%), Portugal (Davianna, 82.63\%) and Poland (Barceloński, 82.01\%), while the lowest is from 
Iran (Pashmine, 69.30\%) [9,34,54]. The hazelnut cultivars from Oregon and Turkey are characterized as possessing one of the lowest oleic acid contents of $75.90-77.80 \%$ [27,62]. It is well known that high oleic acid concentration leads to longer shelf-life and higher oxidative stability. In the case of linoleic acid (C18:2), cultivars from Turkey (14.8-15.0\%) and the USA (12.50-13.11\%) display the highest concentration, whereas the lowest is found in oils from Italy $(7.57-9.22 \%)[27,54,62]$. The linoleic acid concentrations of cultivars from other countries range from $9.84 \%$ to $11.58 \%$. The higher the linoleic acid content, the lower the oxidative stability, and a 100-200-fold more intense chemical rancidification occurs in hazelnut oil $[63,64]$. The oleic and linoleic acid ratio is an important characteristic to evaluate kernel quality. Hazelnut cultivars with a high oleic to linoleic acid ratio generally have higher oxidative stability and a longer shelf life than those with a low oleic to linoleic acid ratio [65].

According to current reports, hazelnuts from Italy, Portugal, and Poland should show the best shelf-life quality parameters [9,34,54]. Cittadini et al. [58] showed that the oleic acid concentration in hazelnut exhibits minor variations among geographical provinces, which is inconsistent with our findings, where the values vary differently and depend on the geographical origin. Similarly, Tüfekci and Karatas [66] reported that it is possible to determine the geographical origin of Turkish hazelnut cultivars based on the differences between SFA (saturated fatty acids) and PUFA (polyunsaturated fatty acids) concentrations. Palmitic (C16:0) and stearic (C18:0) acids show the highest percentage in the cultivar from Iran (Pashmine), 9.60\% and 4.10\%, respectively [33], whereas other cultivars are comprised of lower ranges (4.80-6.52\% and $1.75-3.4 \%$ for palmitic and stearic acids, respectively). Linolenic acid (C18:3) is observed at a very low amount in each cultivar (under $0.5 \%$ ).

As expected, monounsaturated fatty acid (MUFA) is the principal group of fatty acids, followed by polyunsaturated fatty acids (PUFA) and saturated fatty acids (SFA) (Figure 2). The total percentage of SFA is observed in the lowest proportion of hazelnut cultivars from Poland and Portugal, $7.02-7.67 \%$ and $6.97-7.77 \%$, respectively, whereas the highest is found in the hazelnut cultivar from Iran $(13.11 \%)[9,33,34]$. Hazelnut from Europe possesses the lowest SFA content in comparison to other cultivars. The total MUFA shows the lowest concentration in the hazelnut from Turkey $(77.81-80.90 \%)$ and Iran $(79.3 \%)$, whereas the highest are found in cultivars from Italy $(81.92-83.91 \%)$, Portugal (81.60-83.05\%), and Poland (81.74-82.15\%) [9,27,33,34,54]. In cultivars from Turkey are displayed the highest percentage content of PUFA (12.70-15.12\%) and cultivars from Italy show the lowest concentration (7.66-9.35\%) [27,54], whereas in other cultivars, the PUFA concentration is within narrower ranges (10.00-11.24\%). The highest UFA/SFA ratio is observed for cultivars from Poland (12.04-13.25) and Portugal (11.87-13.35), and the lowest in the Pashmine (Iran) cultivar (6.81). The higher the UFA/SFA ratio, the higher the nutritional value of nuts. Bacchetta et al. [54] reported that the major fatty acid is oleic acid in 75 hazelnut oils from different cultivars with an average value of $80.63 \%$, which is inconsistent with our findings. 


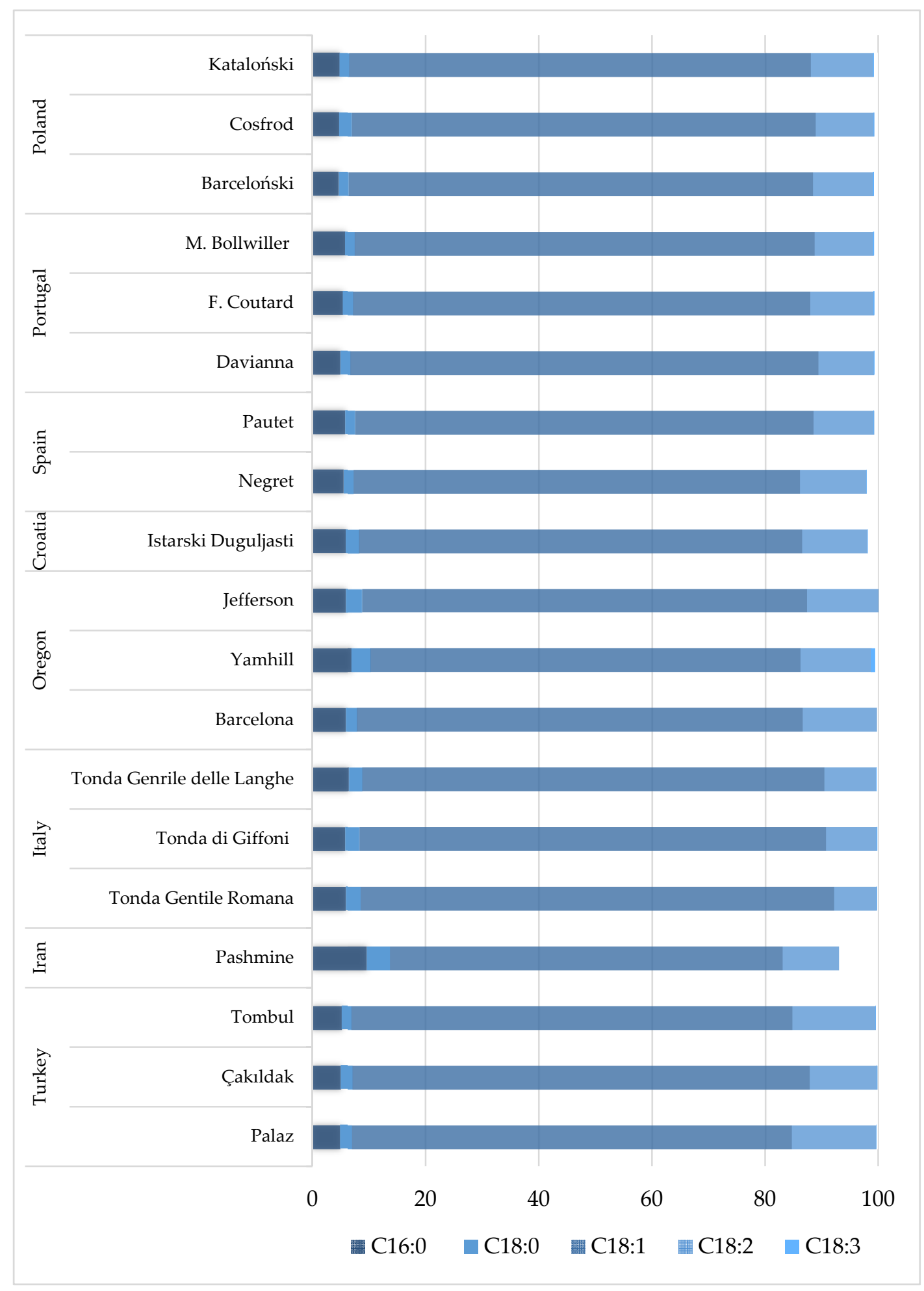

Figure 1. Composition of the main fatty acids (\%) in hazelnut from different cultivars and origins. Main fatty acids, where: C16:0— palmitic acid; C18:0—stearic acid; C18:1c9—oleic acid; C18:2—linoleic acid; C18:3-linolenic acid. References: Poland: Król et al. [34]; Portugal: Oliveira et al. [9]; Spain: Rovira et al. [50]; Croatia: Vujevic et al. [67]; Oregon: Wang et al. [62]; Italy: Bacchetta et al. [54]; Iran: Rezaei et al. [33]; Turkey: Koksal et al. [27]. 


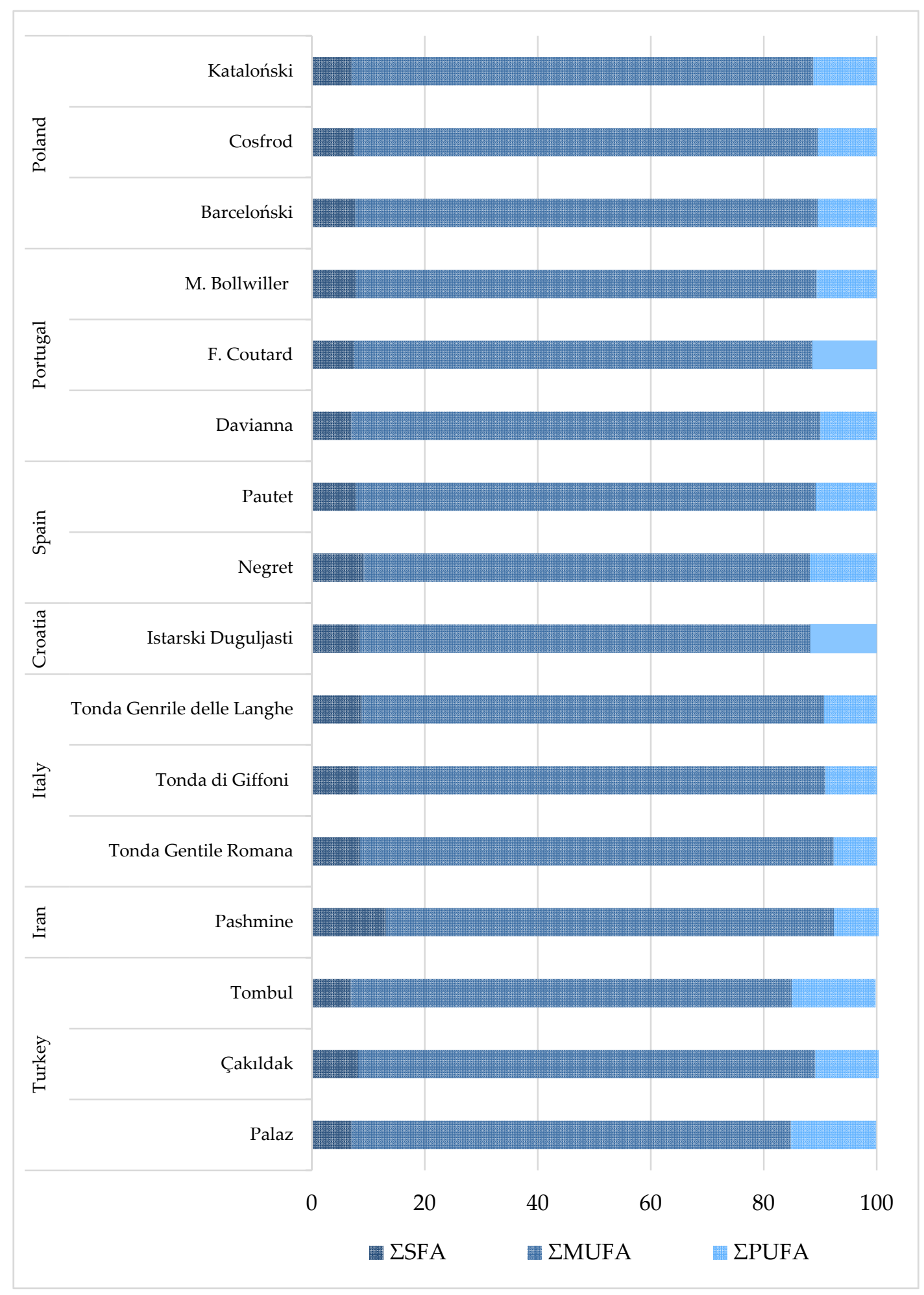

Figure 2. Fatty acid profile (\%) in hazelnut from different cultivars and origins. Fatty acid profile, where: SFA—saturated fatty acids; MUFA—-monounsaturated fatty acids. References: Poland: Król et al. [33]; Portugal: Oliveira et al. [9]; Spain: Rovira et al. [50]; Croatia: Vujevic et al. [67]; Italy: Bacchetta et al. [54]; Iran: Rezaei et al. [33]; Turkey: Koksal et al. [27].

Rovira et al. [50] showed that the main differences between the hazelnut cultivars are related to the PUFA and MUFA content. However, in our study, each fatty acid constituent varied differently. The differences found between the hazelnut cultivars are not only due to variation in climatic conditions 
and origin, but also the fatty acid profile can significantly depend on the stage of growth when the hazelnuts are investigated, storage time and conditions. Palmitic, linoleic and linolenic acids show an increasing trend with respect to the stage of growth, whereas stearic acid decreases, and the unsaturated/saturated fatty acid ratio exhibits a constant increase during the nut's development for all cultivars [28]. During storage, the total saturated fatty acid content increases, while the total unsaturated fatty acid content decreases. These changes are significant and related to the decrease in linoleic acid content as the result of peroxidation [30]. Pritchard et al. [68] reported that if the amount of oleic acid increases in oily seed, then the percentage of linoleic and linolenic acid decreases, additionally, and high temperatures and rainfall increases the amount of oleic acid. Furthermore, Cristofori et al. [69] suggested that the fatty acid composition of hazelnut grown in colder regions contains more unsaturated fatty acids than those grown in hot and dry regions, which is in agreement with the results obtained in this review.

Furthermore, the differences between the fatty acid composition are also due to the extraction method and solvents. In general, the fatty acid percentage of nut oils obtained by Soxhlet extraction was lower than those of the direct cold-pressed oil, probably due to the higher impurities content [69]. Wang et al. [62] obtained oil by classical solvent extraction from powdered kernels; while Król et al. [34] used the cold-pressing method; in other studies, the Soxhlet method was applied. Cold extraction method could give a high oil yield without any major effect on the quality of the extracted oil, while the Soxhlet method has a high process time and temperature, which has adverse effects on oil quality [70,71].

The studies also show that the type of used solvent affects the fatty acid composition; therefore, it is necessary to choose an appropriate extraction method for the compounds of interest [72]. Gao et al. [73] showed that the polarity of the solvents could be the main factor affecting the oil yield (\%) and fatty acid composition. Moreover, the linoleic acid content in the different solvent-extracted samples was significantly different (Folch $>$ ethyl acetate $>$ petroleum ether $>$ acetone $>$ n-hexane). In addition, n-hexane gave a higher oleic acid content than the other solvents. Although the differences in total MUFA and PUFA contents obtained with the different solvents were obvious, there was no significant difference in the SFA. In most of the cited studies, to obtain the fatty acid methyl esters (FAME), the n-hexane was used as a solvent.

\section{Tocopherols Composition}

Tocopherols are among the main components of hazelnut oils, with $\alpha$-tocopherol being the predominant form. Its $\alpha$-isomer is a known strong antioxidant, while $\gamma$-isomer is considered important for the protection of cell membranes from free radical damage [74]. Research on tocopherol composition in hazelnut cultivars has not been thoroughly investigated in countries such as Chile, Serbia, and Iran. Moreover, information regarding minor tocopherol isomer content, mainly $\delta$-tocopherol, is limited (Table 3). According to current reports, the order tocopherol isomer content in hazelnut oil is as follow: $\alpha$-tocopherol $>\beta$-tocopherol $>\gamma$-tocopherol $>\delta$-tocopherol $[8,35]$. The major tocopherol isomer, $\alpha$-tocopherol, represents $69 \%-96 \%$ of total tocopherols. The lowest tocopherol concentration is observed in cultivars from Turkey (69-87\%) [10], whereas the highest concentration is from Croatia and Portugal, $96 \%$ and $92-94 \%$, respectively $[9,74]$. The highest $\alpha$-tocopherol concentration is found in hazelnuts from Poland and Croatia, $25.77-29.60 \mathrm{mg} / 100 \mathrm{~g}$, and $26.8 \mathrm{mg} / 100 \mathrm{~g}$, respectively $[35,75]$. $\gamma$-tocopherol and $\delta$-tocopherol are only present at low levels and are even undetectable in certain cultivars. The sum of $\beta+\gamma$-tocopherol in cultivars is stable, however, the highest percentage is observed in cultivars from Turkey. The tocopherol content differences between the cultivars and origins are relatively high, however, these can be due to the applied solvents and analytical methods, and the data can be expressed for the extracted hazelnut oil or the whole nut.

Amaral et al. [8] examined the $\gamma$ - and $\beta$-tocopherol concentrations over three harvesting years, in which small differences between hazelnut cultivars are observed, whereas no significant differences are observed in $\alpha$-tocopherol concentration. Moreover, they state that minor differences occur due to 
tocopherols concentration and the geographical origin of hazelnut. Taş and Gokmen [10] show that the harvest year contributes to $\alpha$-tocopherol concentration. Furthermore, in the case of hazelnuts, there is no clear relationship between tocopherol content and water deficiency. However, studies have shown that other oily plants promote tocopherol synthesis under water stress $[75,76]$, and that tocopherol is slightly higher in a water deficit environment. In olive oil, the total tocopherols and $\alpha$-tocopherol are highly influenced by crop-year rainfalls, with the highest concentration being found during the driest year [77]. The increase in tocopherol content might contribute to the prevention of plant oxidative damage in drought conditions [78]. Furthermore, the differences between isomer content are due to different extraction methods and conditions, which might have caused difference. As reported by Durmaz and Gokmen [56] mechanically pressed hazelnut oil was found to be richer in all tocopherol isomers than solvent-extracted oil. Through the whole refining process (such as neutralization, deodorization, bleaching), due to the several extreme chemical and physical conditions, an $8-10 \%$ decrease in the amounts of tocopherols is observed [79].

Table 3. Tocopherol homologue concentration in hazelnut oil from different cultivars and origins.

\begin{tabular}{|c|c|c|c|c|c|c|}
\hline Origin & Cultivar & $\begin{array}{c}\beta+\gamma- \\
\text { tocopherol }\end{array}$ & $\delta$-tocopherol & $\alpha$-tocopherol & $\begin{array}{c}\text { Total } \\
\text { Tocopherol }\end{array}$ & References \\
\hline \multirow{3}{*}{ Oregon } & Barcelona & $0.32 * a$ & - & 11.20 & 11.52 & \multirow{3}{*}[62]{} \\
\hline & Yamhill & 0.39 & - & 14.30 & 14.69 & \\
\hline & Jefferson & 0.39 & - & 12.90 & - & \\
\hline \multirow[t]{2}{*}{ Croatia } & Istarski Duguljasti & $9.70 * *$ & - & 268.00 & 277.70 & \multirow{2}{*}{ [74] } \\
\hline & Tonda Gentile Romana & 0.97 * & - & 15.77 & - & \\
\hline \multirow[t]{3}{*}{ Italy } & Tonda di Giffoni & 0.35 & & 15.67 & - & \multirow[t]{2}{*}{ [42] } \\
\hline & $\begin{array}{l}\text { Tonda Gentile delle } \\
\text { Langhe }\end{array}$ & 0.52 & - & 14.93 & - & \\
\hline & Barceloński & $2.68 *$ & 0.27 & 28.67 & 31.62 & \multirow{3}{*}{ [35] } \\
\hline \multirow[t]{3}{*}{ Poland } & Cosfrod & 3.17 & 0.27 & 25.77 & 29.21 & \\
\hline & Kataloński & 2.41 & 0.22 & 29.60 & 32.23 & \\
\hline & Davianna & $10.49-12.14$ ** & $0.61-0.70$ & $165.96-176.54$ & $179.27-188.19$ & \multirow{3}{*}{ [8] } \\
\hline \multirow[t]{2}{*}{ Portugal } & F. Coutard & 7.70-10.59 & $0.27-0.31$ & $146.86-182.84$ & $155.13-193.85$ & \\
\hline & M. Bollwiller & $8.33-9.48$ & $0.76-0.96$ & $133.96-158.38$ & $143.61-168.48$ & \\
\hline \multirow{3}{*}{ Spain } & Negret & - & - & $196.56^{* * *}$ & - & \multirow{2}{*}{ [54] } \\
\hline & Pautet & - & - & 245.60 & - & \\
\hline & Palaz & $3.18-5.37^{*}$ & - & $13.20-19.00$ & $18.60-22.20$ & \multirow{3}{*}{ [10] } \\
\hline \multirow[t]{2}{*}{ Turkey } & Çakıldak & $4.32-4.38$ & - & $15.0-19.90$ & $19.4-24.30$ & \\
\hline & Tombul & $4.90-6.03$ & - & $16.0-36.30$ & $22.0-41.20$ & \\
\hline
\end{tabular}

'-'-no data; ${ }^{\text {a }}$-only $\gamma$-tocopherol; * data are expressed in $\mathrm{mg} / 100 \mathrm{~g}$ of oil; ${ }^{* *}$ data are expressed as a $\mathrm{mg} / \mathrm{kg}$ of nut; ${ }^{* * *}$ data are expressed as ppm of oil.

\section{Knowledge Gaps and Future Prospects}

The present review of the literature on the morphological traits and chemical composition of hazelnut from different geographical origins has identified some gaps in the knowledge or inconsistencies regarding hazelnut quality, morphological and chemical characteristics:

- The in-depth research concerning genetic and/or metabolomic markers of hazelnut from different geographical origins should be implemented to better understand cultivar characteristics and the differences between them;

- Despite a growing production and cultivation area in China and Azerbaijan, there are no studies concerning the effect of agroclimatic conditions on the phenological characteristic, nutritional value, fatty acid composition and fruit quality of hazelnut;

- Moreover, in countries such as Chile or the US (Oregon), with constantly increasing production, information about the quality of the harvested hazelnut is limited;

- Currently on the market, there is an increasing interest in hazelnut by consumers and producers, but some studies are older than 20 years (especially data from Spain and Portugal), making some information already outdated and in need of revision; 
- Our findings also highlight knowledge gaps, such as morphological characteristics in cultivars from Chile, Oregon, Portugal, and Spain, which are necessary to project processing lines and new food products;

- Tocopherol composition in hazelnut has not been thoroughly investigated in the literature, information about minor isomers are especially limited, as are data concerning cultivars growing in Chile, Serbia, and Iran;

- Research on fatty acid composition in hazelnut has been widely studied, other than in countries such as Chile and Serbia;

- Furthermore, information about the influence of agroclimatic conditions on the formation of proteins and carbohydrates and its influence on sensory properties is limited;

- Moreover, the recommended list of cultivars which are high yielding and enable good quality harvest, as well as adhere to the criteria of the global market, should be created for each new producing country in accordance with climate requirements, that may be useful to food-processing companies to enhance the utilization of hazelnut cultivars from non-traditional orchards and origins.

\section{Conclusions}

Morphological trait measurements are commonly used to quantify the genetic variation of accessions performance under normal growing environments, and coupled with nutritional value, affecting the hazelnut quality and taste. This information is valuable for the food processors and industry to choose the appropriate hazelnut cultivars for their purpose. Furthermore, hazelnut cultivars from countries with a low production rate are characterized by similar or even higher nutritional and technological quality, which could make them competitive on the international market.

Author Contributions: Conceptualization, K.K. and M.G.; software, K.K.; validation, M.G.; formal analysis, K.K.; investigation, K.K.; resources, K.K.; data curation, M.G.; writing—original draft preparation, K.K.; writing-review and editing, K.K.; visualization, K.K; supervision, M.G.; project administration, M.G.; funding acquisition, M.G. All authors have read and agreed to the published version of the manuscript.

Funding: This research received no external funding.

Conflicts of Interest: The authors declare no conflict of interest.

\section{References}

1. FAOSTAT. Food and Agricultural Organization of the United Nations. 2018. Available online: http: //www.fao.org/faostat/en/\#data/QC (accessed on 10 March 2020).

2. Technavio. Global Hazelnut Market 2017-2021; EMIS Intelligence Database; Technavio: London, UK, 2017.

3. Silvestri, C.; Bacchetta, L.; Bellincontro, A.; Cristofori, V. Advances in cultivar choice, hazelnut orchard management, and nut storage to enhance product quality and safety: An overview. J. Sci. Food Agric. 2020. [CrossRef] [PubMed]

4. Baldi, S. Italian Tree Nuts 2010; USDA's Global Agricultural Information Network (GAIN): Rome, Italy, 2010.

5. Inaudi, P.; Giacomino, A.; Malandrino, M.; La Gioia, C.; Conca, E.; Karak, T.; Abollino, O. The Inorganic Component as a Possible Marker for Quality and for Authentication of the Hazelnut's Origin. Int. J. Environ. Res. Public Health 2020, 17, 447. [CrossRef]

6. Simsek, A.; Aykut, O. Evaluation of the microelement profile of Turkish hazelnut (Corylus avellana L.) varieties for human nutrition and health. Int. J. Food Sci. Nutr. 2007, 58, 677-688. [CrossRef]

7. Bolling, B.W.; Chen, C.O.; Mckay, D.L.; Blumberg, J.B. Tree nut phytochemicals: Composition, antioxidant capacity, bioactivity, impact factors. A systematic review of almonds, Brazils, cashews, hazelnuts, macadamias, pecans, pine nuts, pistachios and walnuts. Nutr. Res. Rev. 2011, 24, 244-275. [CrossRef] [PubMed]

8. Amaral, J.S.; Casal, S.; Citová, I.; Santos, A.; Seabra, R.M.; Oliveira, B.P.P. Characterization of several hazelnut (Corylus avellana L.) cultivars based in chemical, fatty acid and sterol composition. Eur. Food Res. Technol. 2006, 222, 274-280. [CrossRef] 
9. Oliveira, I.; Sousa, A.; Morais, J.S.; Ferreira, I.C.F.R.; Bento, A.; Estevinho, L.; Pereira, J.A. Chemical composition, and antioxidant and antimicrobial activities of three hazelnut (Corylus avellana L.) cultivars. Food Chem. Toxicol. 2008, 46, 1801-1807. [CrossRef]

10. Taş, N.G.; Gökmen, V. Phenolic compounds in natural and roasted nuts and their skins: A brief review. Curr. Opin. Food Sci. 2017, 14, 103-109. [CrossRef]

11. Rezaei, A.; Ghanati, F.; Behmanesh, M.; Mokhtari-Dizaji, M. Ultrasound-Potentiated Salicylic Acid-Induced Physiological Effects and Production of Taxol in Hazelnut (Corylus Avellana L.). Cell Cult. Ultrasound Med. Biol. 2011, 37, 1938-1947. [CrossRef]

12. Miele, M.; Mumot, A.M.; Zappa, A.; Romano, P.; Ottaggio, L. Hazel and other sources of paclitaxel and related compounds. Phytochem. Rev. 2012, 11, 211-225. [CrossRef]

13. Hoffman, A.; Shahidi, F. Paclitaxel and other taxanes in hazelnut. J. Funct. Foods 2009, 1, 33-37. [CrossRef]

14. Phuc, D.; Popovich, D. Screening for paclitaxel and other taxanes in kernel and shell of Corylus avellana (Hazelnut). J. Pharmacogn. Phytochem. 2017, 6, 247-254.

15. Hosseinpour, A.; Seifi, E.; Javadi, D.; Ramezanpour, S.S.; Molnar, T.J. Nut and kernel characteristics of twelve hazelnut cultivars grown in Iran. Sci. Hortic. (Amsterdam) 2013, 150, 410-413. [CrossRef]

16. Ghisoni, S.; Lucini, L.; Rocchetti, G.; Chiodelli, G.; Farinelli, D.; Tombesi, S.; Trevisan, M. Untargeted metabolomics with multivariate analysis to discriminate hazelnut (Corylus avellana L.) cultivars and their geographical origin. J. Sci. Food Agric. 2020, 100, 500-508. [CrossRef] [PubMed]

17. Mehlenbacher, S.A. Incompatibility alleles of hazelnut cultivars. Acta Hort. 2014, 1052, 107-116. [CrossRef]

18. Gürcan, K.; Mehlenbacher, S.A.; Köse, M.A.; Balık, H.I. Population structure analysis of European hazelnut (Corylus avellana). Acta Hort. 2018, 1226, 87-92.

19. Klockmann, S.; Reiner, E.; Bachmann, R.; Hackl, T.; Fischer, M. Food Fingerprinting: Metabolomic Approaches for Geographical Origin Discrimination of Hazelnuts (Corylus avellana) by UPLC-QTOF-MS. J. Agric. Food Chem. 2016, 64, 9253-9262. [CrossRef]

20. Locatelli, M.; Coïsson, J.D.; Travaglia, F.; Cereti, E.; Garino, C.; D’Andrea, M.; Martelli, A.; Arlorio, M. Chemotype and genotype chemometrical evaluation applied to authentication and traceability of "Tonda Gentile Trilobata" hazelnuts from Piedmont (Italy). Food Chem. 2011, 129, 1865-1873. [CrossRef]

21. Ilić, P.; Mićić, N.; Đurić, G.; Tojnko, S.; Solar, A.; Bosančić, B. Pomological identification of hazelnut cultivars (Corylus avellana L.) in plantations Bosnia and Herzegovina. Agric. Conspec. Sci. 2017, 84, 389-395.

22. Ciarniello, L.F.; Mazzeo, M.F.; Minasi, P.; Peluso, A.; De Luca, A.; Piccirillo, P.; Siciliano, R.A.; Carbone, V. Analysis of different european hazelnut (Corylus avellana L.) cultivars: Authentication, phenotypic features, and phenolic profiles. J. Agr. Food Chem. 2014, 62, 6236-6246. [CrossRef]

23. Petriccione, M.; De Luca, A.; Ciarmiello, L.F.; Piccirillo, P. Carpological and molecular uniformity within the "Tonda di Giffoni" hazelnut. Acta Hortic. 2009, 845, 181-186. [CrossRef]

24. Caligiani, A.; Coisson, J.D.; Travaglia, F.; Acquotti, D.; Palla, G.; Palla, L.; Arlorio, M. Application of 1H NMR for the characterisation and authentication of "Tonda Gentile Trilobata" hazelnuts from Piedmont (Italy). Food Chem. 2014, 148, 77-85. [CrossRef] [PubMed]

25. Ozdemir, F.; Akinci, I. Physical and nutritional properties of four major commercial Turkish hazelnut varieties. J. Food Eng. 2004, 63, 341-347. [CrossRef]

26. Pelvan, E.; Olgun, E.Ö.; Karadağ, A.; Alasalvar, C. Phenolic profiles and antioxidant activity of Turkish Tombul hazelnut samples (natural, roasted, and roasted hazelnut skin). Food Chem. 2018, 244, 102-108. [CrossRef] [PubMed]

27. Köksal, A.I.; Artik, N.; Şimşek, A.; Güneş, N. Nutrient composition of hazelnut (Corylus avellana L.) varieties cultivated in Turkey. Food Chem. 2006, 99, 509-515. [CrossRef]

28. Cristofori, V.; Bertazza, G.; Bignami, C. Changes in kernel chemical composition during nut development of three Italian hazelnut cultivars. Fruits 2015, 70, 311-322. [CrossRef]

29. Oddone, M.; Aceto, M.; Baldizzone, M.; Musso, D.; Osella, D. Authentication and traceability study of hazelnuts from Piedmont, Italy. J. Agric. Food Chem. 2009, 57, 3404-3408. [CrossRef]

30. Ghirardello, D.; Contessa, C.; Valentini, N.; Zeppa, G.; Rolle, L.; Gerbi, V.; Botta, R. Effect of storage conditions on chemical and physical characteristics of hazelnut (Corylus avellana L.). Postharvest Boil. Technol. 2013, 81, 37-43. [CrossRef] 
31. Lucchetti, S.; Ambra, R.; Pastore, G. Effects of peeling and/or toasting on the presence of tocopherols and phenolic compounds in four Italian hazelnut cultivars. Eur. Food Res. Technol. 2018, 244, 1057-1064. [CrossRef]

32. Von Bennevitz, E.; Ramirez, C.; Cazanga-Solar, R.; Losak, T.; Alba-Mejia, J.E.; Maureire-Butler, I. Phenology, pollen synchronization and fruit characteristics of European hazelnut (Corylus avellana L.) cv. Tonda de Giffoni in three sites of central Chile. Rev. Fac. Cienc. Agrar. UNCuyo 2019, 51, 55-67.

33. Rezaei, F.; Bakhshi, D.; Ghazvini, R.F.; Majd, D.J.; Pourghayoumi, M. Evaluation of fatty acid content and nutritional properties of selected native and imported hazelnut (Corylus avellana L.) varieties grown in Iran. J. Appl. Bot. Food Qual. 2014, 87, 104-107.

34. Król, K.; Gantner, M.; Piotrowska, A. Morphological Traits, Kernel Composition and Sensory Evaluation of Hazelnut (Corylus avellana L.) Cultivars Grown in Poland. Agronomy 2019, 9, 703. [CrossRef]

35. Król, K.; Gantner, M.; Piotrowska, A.; Hallmann, E. Effect of Climate and Roasting on Polyphenols and Tocopherols in the Kernels and Skin of Six Hazelnut Cultivars (Corylus avellana L.). Agriculture 2020, 10, 36. [CrossRef]

36. Ciemniewska-Zytkiewicz, H.; Verardo, V.; Pasini, F.; Bryś, J.; Koczoń, P.; Caboni, M.F. Determination of lipid and phenolic fraction in two hazelnut (Corylus avellana L.) cultivars grown in Poland. Food Chem. 2015, 168, 615-622. [CrossRef] [PubMed]

37. Marzocchi, S.; Pasini, F.; Verardo, V.; Ciemniewska-Żytkiewicz, H.; Caboni, M.F.; Romani, S. Effects of different roasting conditions on physical-chemical properties of Polish hazelnuts (Corylus avellana L. var Kataloński). LWT 2017, 77, 440-448. [CrossRef]

38. Revord, R.; Lovell, S.; Molnar, T.; Wolz, K.J.; Mattia, C. Germplasm development of underutilized temperate U.S. tree crops. Sustainability 2019, 11, 1546. [CrossRef]

39. Ellena, M.; Sandoval, P.; Gonzalez, A.; Jequier, J.; Contreras, M.; Grau Beretta, P. Chilean hazelnut situation and perspectives. Acta Hortic. 2012, 1052, 329-342. [CrossRef]

40. Ji, J.; Ge, Z.; Feng, Y.; Wang, X. Lipid characterization of Chinese wild Hazelnuts (Corylus Mandshurica maxim.). J. Oleo Sci. 2019, 68, 13-20. [CrossRef]

41. Milošević, T.; Milošević, N. Cluster drop phenomenon in hazelnut (Corylus avellana L.). Impact on productivity, nut traits and leaf nutrients content. Sci. Hortic. 2014, 148, 131-137. [CrossRef]

42. Bignami, C.; Bertazza, G.; Cristofori, V.; Troso, D. Kernel quality and composition of hazelnut (Corylus avellana 1.) Cultivars. Acta Hortic. 2005, 686, 477-484. [CrossRef]

43. Cristofori, V.; Bizzarri, S.; Silvestri, C.; Muleo, R.; Rugini, E.; De Salvador, F.R. First evaluations on vegetative and productive performance of many hazelnut cultivars in latium region. Acta Hortic. 2014, 1055, 91-97. [CrossRef]

44. Cristofori, V.; Pica, A.L.; Silvestri, C.; Bizzarri, S. Phenology and yield evaluation of hazelnut cultivars in latium region. Acta Hortic. 2018, 1226, 123-130. [CrossRef]

45. Karata, S.; Islam, A.; Tonkaz, T.; Özkutlu, F.; Rovira, M.; Romero, A.; Cristofori, V.; Silveestri, C.; Sperranza, S.; Cetin, S.; et al. Examination of modern and traditional applications in hazelnut production. Acta Hortic. 2018, 1226, 329-332. [CrossRef]

46. Rovira, M.; Cristofori, V.; Silvestri, C.; Celli, T.; Hermoso, J.F.; Tous, J.; Romero, A. Last results in the evaluation of 'Negret' hazelnut cultivar grafted on non-suckering rootstocks in Spain. Acta Hortic. 2014, 1052, 145-150. [CrossRef]

47. Vujevic, P.; Vahcic, N.; Milinovic, B.; Jelacic, T.; Kazija, D.H.; Cmelik, Z. Pomological traits and proximate chemical composition of Hazelnut (Corylus avellana L.) varieties grown in Croatia. Afr. J. Agric. Res. 2010, 5, 2023-2029.

48. Olsen, J.L.; Mehlenbacher, S.; McCluskey, R.L.; Smith, D. Growing Hazelnuts in the Pacific Northwest: Varieties. 2013. Available online: https//catalog.extension.oregonstate.edu/em9073 (accessed on 1 April 2020).

49. Milošević, T.; Milošević, N. Determination of size and shape features of hazelnuts using multivariate analysis. Acta Sci. Pol. Hortorum Cultus Ogrod. 2017, 16, 49-61. [CrossRef]

50. Rovira, M.; Hermoso, J.F.; Romero, A.J. Performance of hazelnut cultivars from Oregon, Italy, and Spain, in northeastern Spain. Horttechnology 2017, 27, 631-638. [CrossRef]

51. Tous, J.; Romero, A.; Rovira, M.; Hermoso, J.F. Performace of 'Negret' hazelnut cultivar grafted on 4 rootstocks in Catalonia (Spain). Acta Hort. 2009, 845, 89-93. [CrossRef] 
52. Solar, A.; Stampar, F. Characterisation of selected hazelnut cultivars: Phenology, growing and yielding capacity, market quality and nutraceutical value. J. Sci. Food Agric. 2011, 91, 1205-1212. [CrossRef]

53. Mehlenbacher, S.A. Hazelnuts. Genetic Resources in Temperate Fruit and Nut Crops. Acta Hortic. 1991, 290, 789-836.

54. Bacchetta, L.; Aramini, M.; Zini, A.; Di Giammatteo, V.; Spera, D.; Drogoudi, P.; Rovira, M.; Silva, A.P.; Solar, A.; Botta, R.; et al. Fatty acids and alpha-tocopherol composition in hazelnut (Corylus avellana L.): A chemometric approach to emphasize the quality of European germplasm. Euphytica 2013, 191, 57-73. [CrossRef]

55. Zeppa, G.; Rolle, L.; Gerbi, V.; Valentini, N.; Me, G. Application of sensory analysis to characterize new selections of hazelnut. Ind. Aliment. 2000, 39, 1249-1257.

56. Durmaz, G.; Gökmen, V. Effect of refining on bioactive composition and oxidative stability of hazelnut oil. Food Res. Int. 2019, 116, 586-591. [CrossRef] [PubMed]

57. Kvasnička, F. Capillary electrophoresis in food authenticity. J. Sep. Sci. 2005, 28, 813-825. [CrossRef] [PubMed]

58. Cittadini, M.C.; Martín, D.; Gallo, S.; Fuente, G.; Bodoira, R.; Martínez, M.; Maestri, D. Evaluation of hazelnut and walnut oil chemical traits from conventional cultivars and native genetic resources in a non-traditional crop environment from Argentina. Eur. Food Res. Technol. 2020, 246, 833-843. [CrossRef]

59. Torres, M.; Pierantozzi, P.; Searles, P.; Rousseaux, M.; García-Inza, G.; Miserere, A.; Bodoira, R.; Contreras, C.; Maestri, D.M. Olive cultivation in the southern hemisphere: Flowering, water requirements and oil quality responses to new crop environments. Front. Plants Sci. 2017, 8, 1-12. [CrossRef]

60. Hoekstra, F.A.; Golovina, E.A.; Buitink, J. Mechanism of plant desiccation tolerance. Trends Plant Sci. 2001, 6, 431-438. [CrossRef]

61. Locatelli, M.; Coïsson, J.D.; Travaglia, F.; Bordiga, M.; Arlorio, M. Impact of Roasting on Identification of Hazelnut (Corylus avellana L.) Origin: A Chemometric Approach. J. Agric. Food Chem. 2015, 63, 7294-7303. [CrossRef]

62. Wang, W.; Jung, J.; McGorrin, R.J.; Traber, M.G.; Leonard, S.W.; Cherian, G.; Zhao, Y. Investigation of drying conditions on bioactive compounds, lipid oxidation, and enzyme activity of Oregon hazelnuts (Corylus avellana L.). LWT Food Sci. Technol. 2018, 90, 526-534. [CrossRef]

63. Saldana, M.D.A.; Martinez-Monteagudo, S.I. Oxidative Stability of Fats and Oils Measured by Differential Scanning Calorimetry for Food and Industrial Applications. In Applications of Calorimetry in a Wide Context-Differential Scanning Calorimetry, Isothermal Titration Calorimetry and Microcalorimetry; InTech: London, UK, 2013.

64. Pershern, A.S.; Breene, W.M.; LulaI, E.C. Analysis of factors influencing lipid oxidation in hazelnuts (Corylus spp.). J. Food Process. Preserv. 1995, 19, 9-26. [CrossRef]

65. Gama, T.; Wallace, H.M.; Trueman, S.J.; Hosseini-Bai, S. Quality and shelf life of tree nuts: A review. Sci. Hortic. (Amsterdam) 2018, 242, 116-126. [CrossRef]

66. Tüfekci, F.; Karataş, Ş. Determination of geographical origin Turkish hazelnuts according to fatty acid composition. Food Sci. Nutr. 2018, 6, 557-562. [CrossRef]

67. Vujević, P.; Petrović, M.; Vahčić, N.; Milinović, B.; Čmelik, Z. Lipids and minerals of the most represented hazelnut varieties cultivated in Croatia. Ital. J. Food Sci. 2014, 26, 24-30.

68. Pritchard, F.M.; Eagles, H.A.; Norton, R.M.; Salisbury, P.A.; Nicolas, M. Environmental effects on seed composition of Victorian canola. Aust. J. Exp. Agric. 2000, 40, 679-685. [CrossRef]

69. Cristofori, V.; Ferramondo, S.; Bertazza, G.; Bignami, C. Nut and kernel traits and chemical composition of hazelnut (Corylus avellana L.) cultivars. J. Sci. Food Agric. 2008, 88, 1091-1098. [CrossRef]

70. Al Juhaimi, F.; Uslu, N.; Babiker, E.E.; Ghafoor, K.; Mohamed Ahmed, I.A.; Özcan, M.M. The effect of different solvent types and extraction methods on oil yields and fatty acid composition of safflower seed. J. Oleo Sci. 2019, 68, 1099-1104. [CrossRef] [PubMed]

71. Khoddami, A.; Ghazali, H.M.; Yassoralipour, A.; Ramakrishnan, Y.; Ganjloo, A. Physicochemical Characteristics of Nigella Seed (Nigella sativa L.) Oil as Affected by Different Extraction Methods. J. Am. Oil Chem. Soc. 2011, 88, 533-540. [CrossRef]

72. Jedidi, B.; Mokbli, S.; Mohamed Sbihi, H.; Arbi Nehdi, I.; Romdhani-Younes, M.; Ibrahim Al-Resayes, S. Effect of extraction solvents on fatty acid composition and physicochemical properties of Tecoma stans seed oils. J. King Saud Univ. Sci. 2020, 32, 2468-2473. [CrossRef] 
73. Gao, P.; Liu, R.; Jin, Q.; Wang, X. Comparison of solvents for extraction of walnut oils: Lipid yield, lipid compositions, minor-component content, and antioxidant capacity. LWT 2019, 110, 346-352. [CrossRef]

74. Sathe, S.K.; Seeram, N.P.; Kshirsagar, H.H.; Heber, D.; Lapsley, K.A. Fatty acid composition of California grown almonds. J Food Sci. 2008, 73, 607-614. [CrossRef]

75. Ali, Q.; Ashraf, M.; Anwar, F. Physico-chemical attributes of seed oil from drought stressed sunflower (Helianthus annus L.) plants. Grasas Aceites 2009, 60, 475-481.

76. Ali, Q.; Ashraf, M.; Anwar, F. Seed composition and seed oil antioxidant activity of maize under water stress. J. Am. Oil Chem. Soc. 2010, 87, 1179-1187. [CrossRef]

77. Beltrán, G.; Jiménez, A.; del Rio, C.; Sánchez, S.; Martínez, L.; Uceda, M.; Aguilera, M.P. Variability of vitamin $\mathrm{E}$ in virgin olive oil by agronomical and genetic factors. J. Food Compos. Anal. 2010, 23, 633-639. [CrossRef]

78. Munné-Bosch, S.; Peñuelas, J. Drought-induced oxidative stress in strawberry tree (Arbutus unedo L.) growing in Mediterranean field conditions. Plant Sci. 2004, 166, 1105-1110. [CrossRef]

79. Karabulut, I.; Topcu, A.; Yorulmaz, A.; Tekin, A.; Ozay, D.S. Effects of the industrial refining process on some properties of hazelnut oil. Eur. J. Lipid Sci. Technol. 2005, 107, 476-480. [CrossRef]

(C) 2020 by the authors. Licensee MDPI, Basel, Switzerland. This article is an open access article distributed under the terms and conditions of the Creative Commons Attribution (CC BY) license (http://creativecommons.org/licenses/by/4.0/). 